\title{
THE REAPPROPRIATION OF FANTASY IN 21ST-CENTURY AMERICAN FICTION: MICHAEL CHABON'S THE YIDDISH POLICEMEN'S UNION
}

\begin{abstract}
American fiction since 2000 has successfully resisted neat classification by displaying hybridity and versatility that move beyond the postmodern paradigm. This paper starts from Irmtraud Huber's claim that a turn from deconstruction to reconstruction in recent American fiction has been achieved through the use of the fantastic mode, and from Andrew Hoberek's statement that popular genres have been conferred full literary status in American fiction after postmodernism. It then focuses on the peculiar blend of alternative history, political thriller and noir detective story in Michael Chabon's The Yiddish Policemen's Union (2007), and on Chabon's use of genre to explore the ways in which the shifting of geopolitical boundaries turns individuals and groups into victims or winners of territorial rearrangements.
\end{abstract}

Key words: American 21st-century fiction, post-postmodernism, genre fiction, alternative history

American fiction since 2000 has successfully resisted neat classification by displaying a colorful hybridity and thematic versatility that move beyond the postmodern paradigm. This includes, but is not limited to, transnational, ecofeminist, ecomarxist, neorealist and metamodernist approaches, and thematic shifts referred to as "new sincerity" or "new authenticity". Authors such as Michael Chabon, Jonathan Safran Foer, Mark Z. Danielewski, Sherman Alexie and Colson Whitehead combine the postmodern legacy with their own innovative approaches to create profoundly intriguing works. These authors partially revisit postmodern themes, such as the constructedness of metanarratives and official historiography, the elusiveness of absolute truth, and the chaos of contemporary existence. Yet they simultaneously move beyond postmodernism, because they destabilize postmodern irony, redirect attention to story-telling and plot-weaving, and foreground characters and their personal relationships and social ties, consequently practicing cautious optimism. Joseph Dewey therefore sees Chabon as being among those at "the forefront of the post-Pynchon era,

\footnotetext{
"Faculty of Philosophy, University of Sarajevo, Franje Račkog 1, 71000 Sarajevo, Bosnia and Herzegovina; e-mail: sanjasos@hotmail.com, sanja.sostaric@ff.unsa.ba
} 
writers born after 1960" who "studied dense avant-garde postmodern theories about narrative de/reconstruction, fashionable theories that questioned the very legitimacy of language and the viability of the reading act they had each loved since childhood". He concludes:

But these writers, call them post-postmodernists, alarmed by the deadend implications of de/reconstructing books into language experiments, sought to restore narrative to a balance, producing serious fictions that maintain the intellectual reach of formal experimentation, certainly, but reclaim as well the inviting imperative of storytelling. (Dewey 2014: 2)

It has also been recognized that post-millennial fiction prides itself on its emphatic use of popular forms - such as comic books, horror, science-fiction, alternative history, fantasy, mystery, the detective story, and the graphic novel- in a manner that radicalizes the earlier postmodern incorporation of popular genres into "high" fiction. Irmtraud Huber argues in Literature after Postmodernism that a turn from deconstruction to reconstruction in recent American fiction is linked to a "new generation of authors" (including Danielewski, Safran Foer and Chabon) "attempting to find ways of expression that move beyond postmodernist instability and subversion" through their "employment of the fantastic mode" (Huber 2014: 215). According to Huber, the post-postmodern fantastic mode rests on an elusive blend of the realistic and the marvelous/fantastic without privileging one over the other, and abandons the postmodern use of genre based on parody. Instead, new authors "employ various genres in ways that are both self-consciously conspicuous and surprisingly sincere (up to the point of being celebratory), even in those moments in which genre limits and conventions are exposed", to the effect that "genre differences are evaluated and valued for their diverse communicative uses and potentials" (Huber 2014: 217). Similarly, Andrew Hoberek claims that a new trend in American fiction "occurs in the context of what might at first seem like evidence for postmodernism's ongoing influence: the blurring of high and mass culture" (Hoberek 2007: 237). However, Hoberek recognizes that a subtle shift has taken place, resulting in a "difference between the transitional but still self-consciously 'literary' appropriation of popular genres in the work of authors like Barth and Pynchon [...] and a newer tendency to confer literary status on popular genres themselves" (Hoberek 2007: 238).

The peculiar generic blend in Michael Chabon's The Yiddish Policemen's Union (2007) illustrates a general turn towards genre fiction in both Chabon's opus and 21stcentury American fiction generally. Somewhat reminiscent of Philip Roth's The Plot Against America (2004), which marked the arrival of alternative history to the 21 st- 
century literary mainstream, Chabon's generically hybrid novel propels the author's exploration into the ever-shifting nature of geopolitical boundaries between nations, regions and states, and the ways in which this influences individuals and groups, making them victims or winners of the political and historical rearrangement of territories. Roth and Chabon's interest in alternative history in the 2000s completes a long process of the gradual but steady seeping of this genre into mainstream literature since the 1960s, with, for example, Philip K. Dick's publication of The Man in the High Castle (1962). ${ }^{1}$ Chabon's novel is "a stylish genre-busting detective noir murder mystery/political thriller/alternate history sci-fi hybrid" (Dewey 2014: 18) and it testifies to the author's interest in addressing serious historical and political issues through "entertainment", which Chabon insists is the defining feature of the narrative. This legitimization of entertainment in literature reveals Chabon's generational loyalty to popular culture (Chabon was born in 1963), a result of his childhood immersion in the worlds of iconic comic-book superheroes and bizarrely adventurous plots, the fantasy of Tolkien, the bitter comic movies of Woody Allen, the prog-rock psychedelic dreamscapes of Yes, King Crimson and Genesis, Monty Python's intelligent buffoonery, and J. G. Ballard's dystopias. Chabon thus cultivates an intensely undogmatic attitude to genre fiction and unreservedly insists on its literary value, radically obliterating the need for theoretical hairsplitting. In so doing he both builds upon and abandons the legacy of the experimental postmodernists (Barth, Coover, Reed, Gass, Visenor, Acker, Pynchon, and Vonnegut) who are known for defending genre fiction's literary merits.

Chabon's turn from strictly literary fiction occurred in his Pulitzer Prize winning third novel The Amazing Adventures of Kavalier \& Clay (2000), which examines the psychological and identitary significance of comic books from the Golden Era of the 1940s against the historical backdrop of the Holocaust. His involvement with genre is even more direct in his fourth novel Summerland (2002), a young adult fantasy fiction that blends an Americanized Alice in Wonderland type of fantasy with mythology, American folklore and baseball. Chabon's use of genre continues in Final Solution (2004), a seemingly classic detective novella about the retired Sherlock Holmes, who is called to solve the mystery of a missing parrot. This apparently trivial case, however, is directly linked to the historical battle against Nazism and the Holocaust. Finally, 2007 saw the publications of The Yiddish Policemen's Union, and Gentlemen of the Road, the latter being a picaresque adventure fantasy novella about two Jewish hired hands in the medieval Khazar Empire. The Yiddish Policemen's Union is arguably a more radical apologia for the imagination, emphasizing its power in creating a paradoxically unreal and real world for the reader. Chabon's dazzling blend of multiple genres has,

\footnotetext{
${ }^{1}$ An important event for the symbolic canonization of the genre was the 1995 establishment of the Sidewise Award for Alternate History.
} 
since his third novel, been combined with an overt attention to Jewish themes. The Yiddish Policemen's Union presents a more complex exploration into the concept of Jewishness, addressing themes such as the Holocaust, displacement, diaspora, the spatial dimension of identity, religious fundamentalism, and/or the symbolic meaning of the state of Israel.

The Yiddish Policemen's Union belongs to the subcategory of science fiction known as alternat(iv)e history, even though this classification has been occasionally contested on the grounds that alternative histories do not include staples of the sciencefiction genre, such as parallel universes, time-travel, and extraterrestrials. Doležel has suggested that "science fiction projects a future that differs substantially from the actuality of the author's present; counterfactual historical fiction modifies the past to project a present that differs substantially from the actual state of affairs" (Doležel 2010: 107). Since alternative history deviates from what we know as or about reality or history, it may seem that "fantasy" is the more appropriate term. Yet classifying alternative history under fantasy is just as problematic, because a major element of the "fantastic" is its narrative framework of the imagined past deviating from recorded history, while the stories themselves are relatively realistic and devoid of fantastic creatures and events, offering a version of (past) reality that can be easily imagined as plausible or authentic. Hence, alternative histories intersect manifoldly with the present political-historical context. Characteristically, alternative history (or counterfactual historical fiction) presents characters that operate within a detective story, adventure story or similar formulaic genre, which to an extent links alternative histories to conventional fiction. Another link to traditional fiction is the frequent focus on the personal plight of the protagonist, and his/her struggles, quests, relationships, traumas and dilemmas.

Typically impatient with "pigeonholes and categories and labels", Chabon insisted in a 2004 radio interview that "the best science fiction, the best mystery fiction, the best horror fiction ought to be put on a par with the best quote-unquote "literary fiction" (qtd in Lott 2014: 133). Ridiculing the assumption that the seriousness of literary fiction guarantees its quality, and the notion that the popularity of genre fiction contributes to its marginality within artistically demanding circles, Chabon concluded that he "would just have the best 10 percent of everything and would stick it all together in one section and call it fiction and have done with it" (ibid.). Readdressing the issue in his essay collection Maps and Legends (2008), Chabon links genre fiction's negative image to the deeply ingrained misconception that intelligence and depth are not compatible with entertainment, and to another misconception: that genre fiction is too formulaic, and too heavily determined by limiting generic conventions, unlike "true literature, [which is] free (it is to be supposed) of all formulas and templates" 
(Chabon 2008: 8). In contrast, Chabon stresses that conventions and rules exist to be transgressed, challenged, modified, inverted and/or played with. He echoes John Barth in reminding authors of "the cycle of innovation, exhaustion, and replenishment" (Chabon 2008: 11).

In The Yiddish Policemen's Union, Chabon imaginatively recasts World War II history by re-imagining the fate of Jewish Holocaust survivors in the US, and of their Jewish-American descendants. Unlike dystopian imaginings of our planet's bleak future, alternative histories pose intriguing questions about the history, politics and/ or culture of nations or states by playing out scenarios that deviate from the official past. Through drawing attention to dark spots or marginal occurrences by fictionally transfiguring them into actualities, these works not only broaden our historical imagination but inevitably implicate our present. Consequently, alternative histories contain implicit warnings against real contemporary political or social tendencies that the authors recognize as perilous. Therefore, Schneider-Mayerson recommends redirecting attention to the context of alternative histories in order to facilitate political analysis, instead of maintaining a disproportionate critical focus on content (plot, setting, characters) and style (genre), which obscures subtly encoded political issues. Importantly, "context" refers both to the immediate socio-political context of the author and the "context of the characters in each novel: the political, social, and cultural shape of the universe they inhabit" (Schneider-Mayerson 2009: 72). A political reading would then "identify and juxtapose the contexts of the authors and their characters in order to understand the alternate history as a cultural formation" (ibid.).

Moreover, Schneider-Mayerson stresses that alternative history is a quintessentially American genre, popular in the US since the 1990s due to the postCold War political climate, the influence of postmodernism, and developments in publishing. Still, the distortion of official historical narratives links alternative histories and postmodernism only superficially: while postmodern deconstruction is rooted in skepticism about the possibility of an objective (historical or other) "truth", alternative histories question the official historiography to tell "a different story in a traditional way" (Schneider-Mayerson 2009: 67). Instead of undermining the notion of knowable history, alternative histories "reinforce traditional western notions of historiographical objectivity even as they appear to subvert them" (ibid.). The chief concern of alternative history writers is plausibility, which they achieve by at least partially grounding their stories in the official history, thus suggesting that the events described could actually have happened. Therefore, both Roth and Chabon include detailed historical information that supports their imagined scenario (e.g. Roth's 27-page postscript in The Plot Against America). The Yiddish Policemen's Union uses a failed political plan that became a marginal historical footnote: the US Department of the Interior's 1939 
Slattery Report, The Problem of Alaskan Development, produced in the early days of World War II. The report, named for Undersecretary Harry A. Slattery, combined typical American political pragmatism with a humanitarian impulse, recommending the settlement in Alaska of Jewish refugees from Europe. This way, the Jews would be saved from Hitler, and would simultaneously help develop a barren and barely inhabitable territory. The idea came from Harold Ickes, the Secretary of the Interior in the Roosevelt administration, and included a provision for a sixty-year Jewish settlement in Alaska. It is documented that Roosevelt may have briefly considered the proposal, but the Slattery Report was rejected by Congress in 1940. Chabon's narrative diverges from the factual one when he condemns Anthony Diamond, the politician deemed most responsible for the Slattery Report's congressional rejection, to death in a car accident. As a result, the Alaska Settlement Act is passed, allowing Chabon's counterfactual history to unfold. In Chabon's novel, the US government leases the Alaskan territory to the Jews for a period of sixty-years, saving the lives of some four million European Jews, and reducing the number of Jewish victims of the Holocaust from the historical six to a counterfactual two million. Such counterfactual details have earned Chabon accusations of anti-Semitism, or at least irreverence toward Jewish history (e.g. from D. G. Myers in "Chabon's Imaginary Jews"), or of dangerous historical revisionism and minimization of the Holocaust. Nevertheless, Margaret Scanlan plausibly argues that Chabon, and Roth as his most important predecessor, consciously use alternative history to remove the taboo from fictional representations of the Holocaust and liberate themselves from "scrupulous historical accuracy". Chabon's counterfactual history further includes an allied nuclear attack on Berlin in 1946, and dispenses with the nuclear bombs in Japan. The state of Israel is destroyed in 1948 after only three months' existence, due to a bloody war with the Arabs; the region subsequently becomes one of interminable violence, and Jerusalem "a city of blood and slogans painted on the walls, severed heads on telephone poles" (Chabon 2007: 17). In Chabon's 1950s and 1960s, the Cuban War was fought instead of the Vietnam War, the former president John Kennedy married Marilyn Monroe, and the Cold War never happened because post-war Russia never became a political superpower. The novel takes place in the present (in or around 2007, the year of the novel's publication), prior to a central political event called the Reversion: the reclamation of Alaskan territory by the American government. The Alaskan Jews have meanwhile managed to turn the Alaskan district of Sitka into a metropolis with five million inhabitants, surviving both the hostile climate and ethnic tensions with the Native American Tlingit tribe. As the date of the Reversion approaches, the Sitka Jews - apart from the rare (chosen) ones among them who will be granted American citizenship - face an uncertain future of homelessness and exile, with no homeland of Israel to turn to. 
Chabon's Jewish district seems strangely real and unreal, an irresistibly convincing imagined place. His fantasy world is brilliantly constructed from his imagination, down to the minutest details including its climate, local customs and legends, eating habits, the inhabitants and their eccentric ways, the Sitka cityscape, its gossip, and its language: Chabon's version of anglicized Yiddish, which comes with a glossary of terms attached. Therefore, Jake Sudderth situates Chabon's opus within the American dual tradition of naturalist fantasy or fantastic naturalism, which is embedded in the Hollywood tradition, and adventure fiction, including anything from Tarzan to James Bond stories subsequently adapted for the screen. In Maps and Legends, Chabon advocates a creative combination of naturalism and fantasy, and associates such generic in-betweenness with a complex ludism. Echoing Walter Benjamin, Chabon stipulates that "our finest and most consistently interesting contemporary writers are those whose work seems to originate from both traditions [naturalistic and fantastic]" (Chabon 2008: 11). Further, Sudderth points to an interview in which Chabon recognizes a link between entertaining fantastic stories and the theme of imperialism (Sudderth 2014: 217), and stresses the political underside of fantasy through exploring the relationship between the imperial center and its colonies, peripheries, and liminal and marginalized places and spaces. The intertwinement of an alternative history with a geopolitical agenda also defines the main formal-thematic nexus in The Yiddish Policemen's Union. Here, the Christian rightwing government directly sponsors a Jewish orthodox sect in its war against the Palestinians, for the purpose of igniting a global holy war that will trigger the Christian Apocalypse.

The alternative history in The Yiddish Policemen's Union is fused with characteristic elements of the hard-boiled detective story, a genre that flourished in the second half of the 20th century, and that Chabon adopts by emulating authors Raymond Chandler and Dashiel Hammett. Chabon even inserts a casual yet astute reference, when protagonist Landsman stumbles upon a "Yiddish translation of Chandler" (Chabon 2007: 305) in his uncle's house, in a novel that translates hard-boiled Chandleresque staples into the Yiddish-speaking Alaskan-Jewish context. In opposition to his conscious foregrounding of the "Jewish roots or antecedents" of certain popular genres (e.g. comic books), Chabon admits to appropriating a genre "where there is no strong Jewish tradition, to take that genre and Judaize it and see what happens" (Hasak-Lowy 2009). Since many science-fiction writers are Jews, Chabon claims in the same interview that he wasn't challenged by that genre and focused instead on "the hard-boiled detective novel, [in which] none of the great masters or key practitioners were Jews" (ibid.). The novel's protagonist Meyer Landsman is a divorced, disillusioned and gloomy alcoholic living in a skid-row hotel, a middle-aged loner who downs his slivovitz shots with almost religious fervor, and increasingly ponders the advantages of suicide $-\mathrm{a}$ 
route both his father and grandfather took. He is a staunch atheist and skeptic ("heaven is kitsch, God a word" [Chabon 2007: 130]), who lives in a peculiar geopolitical heterotopia: Sitka, a temporarily autonomous Jewish district soon to be returned to US control, is officially a secular Jewish state, yet it is controlled from the shadows by its theocratic enclave on Verbov Island. Hence, Landsman is not a "compatriot", as his name ironically suggests, but rather an outsider, both within Sitka and in terms of his imminent status of expatriate and exile. He stoically carries his dark past: his guiltridden father killed himself for having survived the Holocaust; his marriage dissolved after his wife aborted a fetus with genetic abnormalities; and his sister Naomi died in a mysterious plane crash while on a perilous mission that is gradually revealed to be directly linked to the murder Landsman is trying to solve. Landsman is a perceptive and skillful rogue professional, a workaholic with a famous history of closing cases, not least because of his mistrust of others. His personal fractures make him a good detective, but his tough and cynical image indicates a "broken-down masculinity" (Kaminsky 2014: 166), reminiscent of Hemingway's and Faulkner's damaged male protagonists who hide their vulnerability beneath a mask of cynicism and smart talk. The theme of male frailty is introduced by troublesome father-son relationships and the suicides on Landsman's paternal side, and reinforced by his stubborn romantic attachment to his ex-wife Bina Gelbfish, who becomes his superior in the Sitka Police Department at the novel's opening, disintegrating the Hasidic patriarchal frame. That Bina is Meyer's exclusive identity reference rather than his cultural or national identity is another way in which Chabon artistically redefines the Jewish identity to contrast starkly with that of Jewish orthodoxy.

The multigeneric framework sees a detective-story plot intersect with alternative history by gradually morphing into an unraveling political conspiracy with global implications. This serves as a base from which to explore a wider thematic scheme, which Witcombe identifies as Chabon's "firm thematic commitment to issues surrounding Jewish identity" (Witcombe 2016: 31). Landsman's investigation into the murder of a local junkie reveals that the latter used to be both a messianic figure for the local Hasidic Jewish community, and a chess prodigy. This man, Emanuel Lasker (alias Mendel Shpilman), is the only son of the leader of the radical Verbovers, a mafialike organization that controls all the city's shady dealings and has an ultraconservative zero tolerance stance on infidels. Gradually, as the Verbover political alliances with the US government are revealed, Landsman's case becomes a "Jewish case". As this occurs, Chabon's depiction of Jewishness becomes twofold: it incorporates fear and uncertainty about the imminent displacement from Alaska and the subsequent desperate search for a safe and permanent Jewish homeland on one hand, and fanaticism (which nourishes dangerous national romanticism), religious extremism (the Verbovers), 
corruption and unscrupulousness (Hertz Shemets and Alter Litvak), dubious alliances (with Cashdollar and the US), and unspeakable violence (the terrorist plot) on the other. Moreover, Chabon's use of the hard-boiled detective genre establishes a link between the personal and the collective, between Landsman and the Jewish fate. Landsman's rundown hotel is an unsafe, temporary dwelling, as is the urban noir setting of the Jewish district of Sitka; his failed marriage parallels Sitka as a failed project; his personal homelessness and misery are equivalent to the collective misery of the Sitka Jews, the result of imminent political decisions. Therefore, the detective story is "an elaborate metaphor", because its "sole value is in the illustration of the Jewish 'case' rather than the resolution of the particular case which the detectives are asked to solve" (Kaminsky 2014: 163). Further, although Landsman solves Sphilman's murder, his solid detective work cannot undo the global puzzle to which this murder is attached: he can neither stop the Reversion, nor prevent the American-Jewish terrorist plot from happening in Jerusalem. Chabon's deliberate generic subversion of the detective story at this point reinforces the theme of exile and homelessness, and illustrates the impossibility of containing the macropolitical and macrohistorical forces that determine the Jewish case. Although Landsman could be viewed as a paradigmatic Jew because of his pending post-Reversion homelessness and his helplessness within the larger geopolitical scheme, he does achieve a symbolic personal redemption through his reunion with Bina; he even confirms his Jewish identity in a new way, by completely dissociating it from spatial categories. As the personal and collective diverge, the protagonist's small-scale redemption sets the former against the political and historical, emphasizing the impossibility or unnecessity of grand-scale Jewish redemption in the form of a state or a stable political entity. The affirmation of the personal, however, is playfully tied to Chabon's further generic subversion: the revival of Landsman's marriage at the end of the novel contrasts the stereotypical hard-boiled detective's unfulfilled love life as typified by Chandler's Philip Marlowe.

Chabon's Sitka is an imaginary platform that has sufficiently recognizable reverberations from our reality to be an unusually insightful exploration of contemporary Jewish identity. It is envisioned as another failed Jewish utopia; another historical stage in the Jewish history of homelessness and dispossession, interrupted occasionally by provisional and temporary home spaces. No less depressing than the harsh climate and foggy, dark winter landscape is Sitka's economic decline, which is amplified by nostalgic memories of the district's 1977 World's Fair. Besides the significance of the Holocaust and its related historical trauma, Chabon weaves the identity theme around representations of place and space. Tensions with the Tlingit tribe are part of everyday life, symbolized by "the Line". This divides the district into Tlingit and Jewish parts, in a manner reminiscent of the Palestinian-Israeli territorial 
division. The US government's humanitarian objective in opening Alaska to Jewish settlement is questioned by the fact that the Jews have been allotted largely barren, infertile land. As a consequence, various communal projects and farming colonies fail sooner or later, and the sense of doom is reinforced. The undeniable anti-Semitism and the cultural tensions between the Jews and the Tlingit Indians (such as the Synagogue Riots, caused when a synagogue is built too far into Indian territory) foreground the failure of utopian dreams of transnational and intercultural harmony, and eerily echo Jewish-Christian relations before and during the Holocaust. Despite this, the societal rupture is not blamed entirely on the Tlingit. In Chabon's novel, the Jews are not prepared to assimilate, and in their separatist isolationism they insist on their cultural exceptionality. Ironically, both groups are outsiders, persecuted and exterminated throughout history, and both are diasporic nations, inhabiting the island borderlands of the United States, symbolizing their liminal otherness. Nevertheless, the Sitka Jews have readily embraced detachment and insularity, which is Chabon's unequivocal criticism of Jewish cultural autism, both in the novel and in the 21st-century reality. However, Chabon's depiction of the Jewish position is differentiated and subtle, making it impossible for the reader to settle on a simple or one-sided conclusion.

This is best illustrated by the author's depiction of the eruv, maintained by the orthodox Verbovers. The eruv is a powerful, multilayered symbol in the novel, as much as it is an analytical tool. In Jewish Orthodox communities the eruv delineates sacred space: a public space symbolically transformed into a private one by means of poles, strings and natural or man-made landscape markers, such as rivers or railroad tracks. The purpose of the eruv is to relax strict talmudic regulations concerning the carrying of objects outside the home, or using certain means of transportation on the Sabbath. Within the boundaries of an eruv these prohibitions do not apply, since the entire area is treated as an extended "home", allowing believers to move about freely. Literally and symbolically, this boundary-making secures the construction of a home space for orthodox Jews, and reconfirms their collective identity, usually within secular urban neighborhoods. It also underlines the exclusion of non-orthodox Jews and nonJews, and the problematic spatial intrusion into an unmarked public (secular) space. A favorable reading of the eruv would draw attention to its significance as an elaborate spatial symbol that extends beyond religious significance to link Jewish identitymaking to an imaginative feat, thus indicating the permanent (real or metaphorical) precariousness of the Jewish position and the creativity and vitality of Jewish culture. In this sense, the eruv stands for Jewish resourcefulness in hostile circumstances: for the improvisation required to create make-believe and makeshift homes, thus securing physical and mental survival. On the other hand, Chabon uses the eruv to critique orthodox Jewish practices, mostly through Landsman's cynical, wise-guy talk: 
"Landsman has put a lot of work into the avoidance of having to understand concepts like that of the eruv, but he knows that it's a typical Jewish dodge, a scam run on God, that controlling motherfucker" (Chabon 2007: 110). This remark is reminiscent of the heated debates between religious and secular Jews, as well as those between Jewish communities and non-Jewish municipal or civic authorities on the extent and limitations of religious freedom. For example, secular Jews tend to dislike the eruv because to them it symbolizes self-imposed ghettoization, and Chabon (via Landsman) seems to agree. Besides, Landsman's cynical remark points to a paradox that the eruv, although it originates in Jewish religious law, represents a shrewd trick played on God, making it a morally questionable practice that undermines the religious law from which it originates. Importantly, Chabon makes it clear that the eruv is not the only metaphor for Jewish inventiveness in self-preservation, because the theme of the internalized home in his novel moves beyond the eruv symbolism. It is increasingly dissociated from the concrete physical (no matter how provisional) space, invoking the typical self-perception of many Jews outside Israel of being doomed (or blessed) to an eternal diasporic existence. Yet, Chabon converts this life of homelessness, wandering, exile, and perpetual mobility - an eternal Jewish theme - into something more positive: Bina and Landsman, reunited at the novel's end, seem to embrace or accept the advantages of exile as a state of cultural and mental in-betweenness. However, we should bear in mind that such cultural and existential elasticity is primarily imposed from without, making criticisms of Chabon's alleged irreverence and/or ignorance of Jewish history and culture superficial, if not intentionally malicious (Myers). Eventually, the novel foregrounds characters who believe that sanctuary will not be found in exclusivist cultural and religious practices (the eruv), irrational geopolitical agendas rooted in terrorist violence and/or a fundamentalist death wish, but in the ties of love or marriage (Bina and Landsman) and of kinship and friendship (Landsman and Berko Shemets). In the novel, the negative implications of the eruv and the undeniable political subtext of whether Jewishness can or should be maintained outside a historical homeland, combined with Chabon's repeatedly stated view that the state of Israel is an "unnecessary annoyance" (Anderson 2016: 89) have led conservatives to label Chabon an Anti-Zionist. Indeed, Chabon offers, through Landsman, the perspective that Jewish identity is not only not endangered, but "best realized outside of a defined geographic territory; in other words, in diaspora" (ibid.), in accordance with Landsman's credo: "my homeland is in my hat" (Chabon 2007: 368).

Regardless of the Jewish theme and in the context of Chabon's reaffirmation of the fantastic, the eruv becomes a shining metaphor for the power of fantasy to transcend actual (geopolitical) borders and create an alternative sanctuary within one's mind and art. Barbara Mann notes that contemporary conceptual (often Jewish) 
artists have long recognized the symbolic implications of the eruv, with the effect that "the eruv has emerged as both trope and device in critical theory and in art" (Mann 2012: 138). As a trope for artistic procedure, the eruv almost becomes a metafictional commentary on the author's own practice. Chabon thus becomes a doppelgänger of the novel's boundary maven Zimbalist: he determines the rules, limits and outreach of his fantasy world - a faraway, imaginary, doomed Jewish kingdom by the arctic sea and imaginatively transforms the odd and unfamiliar (a strange fantasy about a Jewish state in Alaska) into something likeable and convincing. Chabon's conceit of the artist as an eruv-maker thus testifies to a more general return to the delight in storytelling, world-making and plot-weaving. Simultaneously, as Scanlan remarks, this is "perhaps a twenty-first century shadow of modernism's confidence about the power of art to remake the world" (Scanlan 2011: 526).

The precariousness of the Jewish position in the novel is primarily explored through Sitka's internal divisions, revealed in Landsman's sarcastic remarks about the eruv and the insane exclusivist separatism of the Verbovers, who glare at him as he drives by, letting him know that he is an unwelcome intruder into their world. The Verbovers are villains, a smoothly functioning ruthless criminal organization of hypocrites, who observe strict religious rules only externally. Their circumvention of Sabbath regulations through the eruv symbolizes the pragmatic cunning and deceit the Verbovers have perfected in their unique conjunction of criminality and faith, resting on the gap between a visible ultraorthodox religious image and their invisible underground activity. The Verbovers do the opposite of what they officially profess: instead of sacralizing it, they criminalize the privatized public space, profiting from the socially marginal citizens they despise as derelicts: junkies, prostitutes, drunks, murderers, the poor, and the infidels. The Verbovers' autistic insensitivity to the fate of Sitka's other Jews is confirmed later in the novel, after Landsman finds out that they made a deal with the US government guaranteeing their transfer to Jerusalem after the terrorist mission there is completed. The hyper-real prosperity of Verbover Island is reflected in Landsman's ironic description of it as a "Disney shtetl" (Chabon 2007: 106), a simulated place that invokes corruption, crime and dubious deals. The Verbovers' anachronistic rigidity in creating a replica (whose disneyfied simulacrum is as "bright and clean as a freshly forged birth certificate" [Chabon 2007: 106]) of Jewish life from pre-Holocaust Ukraine is, in view of the epilogue, both useless and madly irrational. The privileged status of the Verbovers compared to that of others in the Jewish district (and worldwide) is emphasized by their prosperity, wealth, and high standard of living, and by the class differences that presuppose their insensitivity to the Jewish position on a transnational level. Thus, Verbover women "sport head scarves and glossy wigs spun from the hair of the poor Jewesses of Morocco and Mesopotamia. Their coats and long dresses are the 
finest rags of Paris and New York, their shoes the flower of Italy", and there is "not one empty storefront" (Chabon 2007: 101) to be seen.

Landsman's mistrust of the Verbovers is confirmed as his investigation uncovers the aforementioned secret deal between them and the rightwing US government, which is led by evangelical Christians. The plan is to wage a war on Arab Palestine, explode the Dome of the Rock and rebuild the Temple in Jerusalem. This way, the state of Israel will be reclaimed by the Jews, and the Verbover community will be transferred there at the US' expense. However, the entire conspiracy is ultimately fueled by the American fundamentalist Christians' belief that rebuilding the Temple in Jerusalem is a prerequisite for the Christian Apocalypse and the Second Coming of Christ. Thus their irrational fanaticism makes the Verbovers the perfect accomplices of the equally fanatical Christians, who are pushing their own agenda. Or, as Bina states: "God damn them all. I always knew they were there. Down there in Washington. Up there over our heads. Holding the strings. Setting the agenda. Of course I knew that. We all knew that" (Chabon 2007: 375). Landsman reveals that a refusal to participate in this insane mission cost Mendel Sphilman his life. However, since Mendel is the disowned only son of the Verbover Rebbe Heskel Sphilman, the Verbovers' insensitivity toward and intolerance of those who do not comply with their norms and commandments is reflected on a personal level. The sensitive and spiritual Mendel was a young man with an IQ of 170, reported to have performed miracles such as healing cancer and intuitively knowing a person's predicament. He was the former pride of the Verbover community and widely believed to be the Messiah. Mendel and his father were estranged for twenty years, since Mendel fled on his wedding day from an arranged marriage intended to suppress rumors of his homosexuality, and refused to be pressured into the predetermined role of Messiah. Pessimistic and hopeless, not least because of his rarely profound insight into human nature, Mendel flees the family and the Verbover community for a heroin addiction on the streets of Sitka. Landsman finds out that Mendel asked Hertz Shemets (Landsman's uncle, and a controversial figure) to shoot him out of desperation, knowing that he has become a walking target after he refused to be a pawn in the Jewish-American terrorist conspiracy. The dark fantasy of a potential savior asking a man for the mercy of a bullet sarcastically implies that, even if the myth of the Messiah's arrival were authentic, the Jews would not deserve him because of their fundamentalist folly. Adapting the postmodern idea that the world would not recognize a Messiah if he came (e.g. in John Barth's Giles Goat-Boy), Chabon imagines a situation in which a potential Messiah is at hand, but the Jews themselves must either actualize or jeopardize their redemption. Therefore, Chabon deliberately avoids making claims about Mendel's authenticity and leaves all possibilities open. In doing so, he suggests that the Verbovers may have destroyed 
their own savior because he does not meet their rigid requirements, being gay and a chess prodigy (both considered transgressions according to orthodox Jewish rules), and uninterested in politics.

Internal Jewish conflicts are further underlined in Chabon's choice of Hertz Shemets as Mendel's murderer: Hertz is largely indifferent toward Mendel as a person, but sees him as a threat to his political counterplan to negotiate a permanent status for Sitka with the Americans. Hertz Shemets is the first Jew to join the FBI with the intention of persuading the US government to nullify the Reversion, offering in exchange decades of (albeit dubious) loyal service. The mastermind behind the aforementioned 1970s Synagogue Riots, Hertz interprets his own actions as disciplining Jewish fanaticism by discouraging Jewish movement "into the disputed areas" (Chabon 2007: 316) because it jeopardizes the Jewish cause in Sitka. As a result of Hertz's decisions, the riots end in violence that claims the life of his own Tlingit wife. The question Chabon seems to be asking is whether Hertz's Holocaust trauma justifies his political activity, summarized for Landsman by Irish-American journalist Brennan as his uncle's "sordid history of corruption, malfeasance, and unconstitutional skullduggery" (Chabon 2007: 66). Chabon's multigeneric novel thus becomes a convenient tool for exploring a contemporary, post-Holocaust, Jewish identity closer to his generation, yet without fully erasing the remembrance and historical trauma of the Holocaust, which are present through the inclusion of characters like Shemets. Although a political nemesis of the Verbovers, Shemets takes an equally erroneous approach. He believes that the Jews must stop yearning for their lost homeland in the Middle East and liberate themselves from the biblical grand narrative of expulsion and return; they must not wait for a Messiah to usher in the last chapter of Jewish history. Conversely, Hertz believes in assimilation, transnational identity and (an often unscrupulous) collaboration with the FBI and the US government. But Hertz's transnational utopia fails, and his loyalty to the US leaves him a broken man, a victim of his own political naivety combined with his mercantilist schemes. Thus, Shemets embodies a differentiated view of Jewish identity as an uneven mixture of genuine concern for his people, adventurous political schemes, and unscrupulous personal gain. Eventually, his corrupt and questionable tactics turn him into a pawn of American rightwing interests, making him an enemy of his people (who he claims to be saving), and leading him to murder Mendel. Symbolically (with overtones of Judas), Hertz kills his Messiah but does not achieve any of his objectives: the Americans betray him and the Reversion is enforced; the Dome of the Rock is exploded anyway in a fit of politico-religious insanity; and the Verbover Zionists are transferred to Jerusalem, as agreed in their previous deal with the US government. ${ }^{2}$

\footnotetext{
${ }^{2}$ Scanlan establishes a parallel between Hertz and the real-life Jewish-American supporters of American
} 
The Jewish-American conspiracy involves critical financial and logistic support from the US government, including the special training of paramilitary agents at the Peril Island facility, which is camouflaged as a ranch. As expected, the Verbovers legitimize their terrorism as a first-class religious mission: during his clandestine investigation on Peril Island, Landsman sees a red heifer on the ranch. He learns only later that it is genetically engineered, created to confirm the biblical legend that the arrival of the Messiah will be announced by a red heifer when the Temple is rebuilt. To Landsman, this indicates that the preparations for the forthcoming apocalypse have entered their terminal phase. This is confirmed by demolition expert Alter Litvak, who reveals that the US president commissioned him to resurrect the Temple of Jerusalem on the ruins of the Dome of the Rock. In the novel's final pages, after the Dome of the Rock has been bombed, the American secret service arrives in Sitka, letting the Verbovers go, but arresting Landsman and Bina.

The responsibility of the US state is by no means downplayed; on the contrary, its policy of using the diasporic Jews of Sitka to work for US national interests and manipulating them with unfulfilled promises emphasizes the inability of the Jews to secure a genuine political stability. Along with being responsible for their own plight, the Jewish actors are tragicomic pawns of American interests. The US government sends troops and warplanes under the pretext of preventing Arab terrorist activity (making bombs under the Temple Mount), in a move reminiscent of the justifications of Operation Iraqi Freedom in our reality. Jerusalem and the Holy Land are reclaimed, Arabs are expelled, streets renamed, and what some (like Landsman) see as a terrorist attack on Muslim holy places, others see as the fulfilling of the Zionist and Christian divine scripts. Chabon ends the novel with images of chaos, catastrophe and imminent doom, and despite "stop[ping] short of folding his story back into actual history", he suggests that "the Middle East in this alternative history will resemble its real-life counterpart, with renewed tensions between Palestinians and Jewish settlers and a US military presence that could be indefinitely prolonged" (Scanlan 2011: 524). There are no innocents on any side.

At the same time, Chabon sensitizes us to post-Holocaust Jewish history, imagining a radical scenario in which the historical trauma of the Holocaust resurfaces at the critical moment when the prospect of a new homelessness emerges. This instigates unspeakable violence and terror in Jerusalem, facilitated by the American superpower that could have prevented it by granting the Sitka Jews a permanent settlement in Alaska, if it were not for the latter's own irrational fundamentalist

liberal politicians like Hillary Clinton, who demand that AIPAC will not compromise the American peace process by endorsing Jewish movement into disputed areas, such as East Jerusalem or the West Bank (Scanlan 2011: 521). 
reasons. We are led to understand how powerlessness, placelessness, dislocation, uncertainty, political manipulation, and frustration fueled by negative historical memory mobilize the radical Jews to a desperate act of terror. In Chabon's alternative universe, the Jews, robbed of their state in 1948, are dangerously resolved to get it back at all costs, which they do at the expense of the other side. At this point, Chabon's alternative history becomes a first-class political fiction, as it opens up into the actual present, sensitizing the readers to the precarious position of the actual losers in 1948 - the Palestinians: "Chabon encourages us to think more fully and generously about the people who actually lost that [Israeli-Arabic] war" (Scanlan 2011: 525), who are currently doomed, like Chabon's Sitka Jews, to uncertainty, humiliation and political and religious instrumentalization. Far from being an apolitical literary exercise, this alternative history allows Chabon to explore the explosive mixture of religion and politics in the Jewish, American, and Jewish-American contexts. Via his fictional Sitka, he casts light on the troubling aspects of America's 21st-century policies on Israel and on Jewish and Jewish-American radicals, which promote and embody fundamentalist Christian and Jewish agendas. Chabon thus exposes a 21st-century rightwing blend of religious and political extremism, which normalizes the tolerance of violence. It is not difficult to recognize in the Verbovers the real Jewish-American Zionists, with their typical mixture of irrationality, insanity and readiness for horrific violence. Chabon's criticism of these Zionist political goals and methods are also evident in Landsman's attitude toward the Verbovers. The bombing of the mosque makes Sitka Jews dance with joy on the streets, as Scanlan reminds us "just as Palestinians were alleged to have done on 9/11" (Scanlan 2011: 523). In this context, even Chabon's invention of a fictionalized Yiddish language and his preference for Yiddish over Hebrew becomes a political statement: Hebrew is favored by the Zionist separatists, who reject Yiddish as the lowbrow language of integrationist European (German) Jews. The novel also references reality through Chabon's refusal to draw a morally clear division between the Jews and the Arabs, and in his decision to expose "the violence in the impulse, which some Christians and Jews share with radical Islam, to remake the present in the image of a dead past" (Scanlan 2011: 519). In interviews, Chabon has repeatedly ridiculed the persistent insanity of trying to enact religious narratives from the past in the present, suggesting that all sides (Jewish, American and Muslim/Arab) are equally obsessed with warmongering fictions, and have equal potential to resort to violence and terrorism.

As the novel draws to a close, Landsman prepares to trade his moral integrity for a green card, and eventually American citizenship, which would enable him and Bina to stay in Sitka after the Reversion. However, in true noir fashion he changes his mind, deciding that he cannot remain silent and pretend not to know about the training facility 
and the American government's support of the catastrophic plan. Landsman contacts a reporter and simultaneously prepares with Bina to leave Sitka, willingly embracing an uncertain future. His choice suggests that "home" is an internalized concept, which requires the embracing of liminality and permanent mobility, but also points to the power of fantasy. All this is represented by Landsman's wife and her enormous tote bag, which symbolizes the "persistence of the race"; the "Jews who carry their homes in an old cowhide bag, on the back of a camel, in the bubble of air at the center of their brains. Jews who land on their feet, hit the ground running, ride out the vicissitudes, and make the best of what falls to hand, from Egypt to Babylon, from Minsk Gubernya to the District of Sitka" (Chabon 2007: 155).

Chabon gives us a Jewish tale with a twist, where homelessness is deliberately embraced as the only moral action available to characters in a world defined by terrorism, fanaticism, duplicity and hypocrisy. Paradoxically, statelessness offers not only the freedom to fantasize, but also freedom from manipulation, to a man whose name echoes old allegiances to territory. After all, Landsman does belong: he is a member of an inwardly charted country. Resistance can also be seen in Mendel's refusal to play Messiah for the radical Verbovers, and to be a pawn in the radical Jewish plot. Thus, ironically, a man who has officially lost his religion becomes a holy figure, while Landsman, an atheist, redeems Mendel by solving the mystery of his murder, and redeems himself by refusing to sell himself for an American passport. Unlike the self-proclaimed saviors of the Jewish people, Mendel Sphilman, a Messiah turned heroin addict, and Landsman Meyer, a cynical atheist turned morally upright hero who refuses a deal from corrupt American agent Cashdollar, are the righteous Jews. In the end, Landsman reconfirms his moral code, wins his wife back, and if he doesn't save the world, he at least makes it a less dark place. Although times are always strange to be a Jew (a recurrent phrase in the novel), Landsman, Bina and Mendel show that there are many roads for a Jew to travel, not all of which lead to Jerusalem-which is probably a good thing.

\section{References}

Anderson, D. (2015). Planet of the Jews: Eruvim, Geography, and Jewish Identity in Michael Chabon's The Yiddish Policemen's Union. Shofar, An Interdisciplinary Journal of Jewish Studies, 33(3), 86-109.

Chabon, M. (2008). Maps and Legends: Reading and Writing along the Borderlands. London: Fourth Estate.

Chabon, M. (2007). The Yiddish Policemen's Union. New York: Harper Collins. 
Dewey, J. (2014). Understanding Michael Chabon (Understanding Contemporary American Literature). Columbia: University of South Carolina Press.

Doležel, L. (2010). Possible Worlds of Fiction and History: The Postmodern Stage. Baltimore: Johns Hopkins University Press.

Hasak-Lowy, T. (2009). The Language Deep, Deep in Chabon's Ear. Jbooks.com

(11 April 2019) <http://www.jbooks.com/interviews/index/IP_HasakLowy_ Chabon.htm>.

Hoberek, A. (2007). Introduction: After Postmodernism. Twentieth Century Literature, 53(3), 233-247.

Huber, I. (2014). Literature after Postmodernism: Reconstructive Fantasies. Basingstoke: Palgrave Macmillan.

Kaminsky, I. (2014). Solving the Jewish Case: Metaphorical Detection in Michael Chabon's The Final Solution and The Yiddish Policemen's Union. In: B. Batchelor et al. (eds.), Michael Chabon's America: Magical Words, Secret Worlds, and Sacred Spaces, Lanham, MD: Rowman and Littlefield, 159-172.

Lott, M. (2014). Genre for Justice: The Final Solution and The Yiddish Policemen's

Union as Reflections of Golden Age Detective Fiction Texts. In: B. Batchelor et al. (eds.), Michael Chabon's America: Magical Words, Secret Worlds, and Sacred Spaces,Lanham, MD: Rowman and Littlefield, 127-139.

Mann, B. E. (2012). Space and Place in Jewish Studies. Piscataway, NJ: Rutgers University Press.

Myers, D. G. (2008). Chabon's Imaginary Jews. The Sewanee Review, 116(4), 572-588. Roth, P. (2004). The Plot Against America. New York: Houghton Mifflin.

Scanlan, M. (2011). Strange Times to Be a Jew: Alternative History after 9/11. Modern Fiction Studies, 57(3), 503-531.

Schneider-Mayerson, M. (2009). What Almost Was: The Politics of the Contemporary Alternate History Novel. American Studies, 50, 3/4, 63-83.

Sudderth, J. (2014). American Prowess Deconstructed: Michael Chabon and the Merger of Naturalism and Fantasy. In: B. Batchelor et al. (eds.), Michael Chabon's America: Magical Words, Secret Worlds, and Sacred Spaces, Lanham, MD: Rowman and Littlefield, 217-234.

Witcombe, M. (2016). A Comedy of Eruvs: (Re)Locating Jewish Identity in Michael Chabon's The Yiddish Policemen's Union and Howard Jacobson's J. Shofar, An Interdisciplinary Journal of Jewish Studies, 34(4), 29-51. 